\title{
ANALISA KEKUATAN SAMBUNGAN RIVET ZIG-ZAG DAN INLINE DENGAN PLAT AL 2024-T3
}

\section{Brilliant Dwinata, Adi Ganda Putra, Fauziyya Hafizha Riana}

Universitas Jendral Achmad Yani (UNJANI) Cimahi Jawa Barat, Indonesia

Email: briliant.dwinata@lecture.unjani.ac.id, adigandaputra@yahoo.com, fauziyya.hafizha@gmail.com

\begin{abstract}
Abstrak
Kualitas sambungan rivet berperan penting untuk menahan beban khususnya pada struktur badan pesawat. Umumnya terdapat dua pengaturan susunan rivet yakni zigzag dan inline. Penelitian ini bertujuan untuk menganalisa kekuatan kedua jenis sambungan rivet tersebut. Pengujian spesimen dilakukan dengan 2 cara, yakni pengujian secara riil yang mengacu pada standard EN ISO 12996:2013 tentang pengujian destruktif pada sambungan dan pengujian secara numerik menggunakan perangkat lunak Ansys 2020 R2. Dua spesimen uji tersebut masing-masing memiliki susunan rivet zig-zag dan inline dengan diameter rivet $\varnothing 3,2 \mathrm{~mm}$ dan pelat Al 2024-T3 tebal $0,8 \mathrm{~mm}$ dan lebar $37 \mathrm{~mm}$. Hasil pengujian Tarik menunjukkan bahwa susunan rivet zig-zag dapat menerima beban maksimum sebesar 6,01 kN sedangkan susunan rivet inline 5,73 kN. Sedangkan pengujian numerik menunjukkan bahwa tegangan maksimum ekuivalen von-Mises pada susunan rivet zig-zag sebesar 930,8 MPa sedangkan susunan rivet inline sebesar $865,1 \mathrm{MPa}$.
\end{abstract}

Kata Kunci: susunan rivet; pengujian tarik; tegangan ekuivalen von-mises; beban tarik

\section{Abstract}

The name rivet makes it important to withstand the weight on the body. There are generally two names that get along with zig-zag and inline. This study is used to analyze the strength of both types of rivets. The test was conducted in 2 ways, namely the real test that was on the standard at en ISO 12996:2013 on destructive tests at that time the ansys 2020 R2 device-thesic system. Two test tests between zig-zag and inline rivet number numbers with a nail diameter of $\emptyset 3.2 \mathrm{~mm}$ and an Al 2024-T3 plate were $0.8 \mathrm{~mm}$ thick and $37 \mathrm{~mm}$ wide. As a result of the pull-only, the zig-zag rivet cabinet can accept a load load of $6.01 \mathrm{kN}$ while the cabinet rivet is $5.73 \mathrm{kN}$ in line. While the numerical trend alone is that the balance voltage equivalent to von-Mises at zig-zag amput is $930.8 \mathrm{MPa}$ while the inline cabinet rivet is $865.1 \mathrm{MPa}$.

Keywords: word rivet; is doing 10 times 1000 voltage equivalent von-mises; tensile load 


\section{Pendahuluan}

Perkembangan teknologi daninformasi, khususnya yang terjadi di indonesia terjadi sangat dinamis. Perkembangan tersebut tentu saja berdampak pada segala bidang, seperti ekonomi, kesehatan, sosial dan tentunya pada bidang pendidikan (Cholik, 2017).

Kemajuan perkembangan teknologi komputer dan telekomunikasi dapat membantu menyelesaikan pekerjaan dengan cepat, akurat dan efisien. Keamanan merupakan aspek yang sangat penting dalam berkomunikasi baik dengan komputer atau perangkat komunikasi lainnya (Hondro, 2018).

Kualitas sambungan rivet berperan penting untuk menahan beban khususnya pada struktur badan pesawat. PT Dirgantara Indonesia merupakan salah satu perusahaan manufaktur pesawat terbang yang menggunakan teknologi penyambungan rivet sebagai proses penyam- bungan utama struktur badan pesawat. Pesawat CASA 212, Helikopter Airbus MK II, CN 235, dan N219 menggunakan material pelat Al 2024-T3 juga menggunakan variasi susunan rivet zig-zag dan inline sebagai proses penyambungan badan pesawat (Zamzamy, 2018).

Kegagalan pada sambungan rivet pada badan pesawat terbang merupakan kombinasi dari tiga faktor: induce stress, thermal fatigue dan vibration. Dari ketiga factor tersebut, induce stress merupakan faktor yang dapat dikendalikan untuk meminimalisasi risiko kegagalan sambungan rivet (Cheraghi, 2008). Induce Stress merupakan tegangan yang terjadi pada saat pesawat terbang beroperasi.

Pengaruh dari parameter proses riveting diteliti oleh Changyi Lei, dkk. Beberapa parameter rivet seperti: squeezing force, struktur rivet, dan diameter lubang memiliki dampak yang lebih signifikan pada kondisi gangguan. Karena struktur rivet dan diameter lubang ditentukan sebelum operasi rivet, squeezing force dianggap sebagai variabel yang paling penting untuk kualitas rivet dari struktur rivet. Hasil menunjukkan bahwa squeezing force merupakan parameter paling penting untuk kualitas rivet (Lei, $\mathrm{Bi}, \mathrm{Li}, \& \mathrm{Ke}, 2017)$.

Standard EN ISO 12996:2013 merupakan standard pengujian destruktif pada sambungan mekanik. Jacek Mucha melakukan penelitian mengenai analisa kekuatan pada beberapa konfigurasi sambungan rivet dengan mengacu pada standar yang sama. Selain itu Jacek juga melakukan pengujian pada temperature yang berbeda, Material plat yang digunakan adalah baja S350GD yang terlapisi seng (Mucha, 2017).

Menurut Rudawska, dkk membandingkan kekuatan sambungan rivet yang dibuat dengan rivet tradisional (dengan lubang yang sudah dibor sebelumnya) dan paku keling menusuk sendiri (SPR) untuk berbagai jenis sambungan. Sambungan paku keling diproduksi menggunakan paku keling baja dan paduan aluminium dan dua jenis bahan pelat: pelat baja 235JR dan pelat paduan aluminium EN AW 6060. Untuk semua sambungan yang diuji, kapasitas beban tertinggi diperoleh untuk sambungan rivet yang ditembus sendiri, sedangkan yang terendah untuk sambungan yang sudah dibor dengan rivet paduan aluminium. Selain itu, ditemukan bahwa kekuatan geser sambungan rivet 
yang ditembus sendiri lebih tinggi dibandingkan dengan paku keling buta aluminium dan baja (Abdullah, Beden, \& Ariffin, 2011).

Tujuan penelitian ini adalah menentukan susunan rivet yang efektif untuk instalasi struktur pesawat udara dengan cara membandingkan susunan rivet zig-zag dan inline dalam aspek kekuatan sambungan. Informasi yang digunakan sebagai nilai pembanding mencangkup nilai beban serta tegangan maksimum pada sambungan rivet.

\section{Metode Penelitian}

Secara umum tahapan kerja penelitian ini meliputi tiga tahapan utama, diantaranya: proses manufaktur kedua spesimen uji, pengujian rill kekuatan kedua sambungan hasil proses rivet dengan metode uji tarik sesuai dengan standard, pemodelan pengujian tarik menggunakan perangkat lunak Ansys 2020 R2, dan menganalisa kekuatan sambungan kedua spesimen uji serta menarik kesimpulan (Agustin, Gandhiadi, \& Oka, 2016).

Spesimen uji dirancang sedemikian rupa sehinga mengacu pada standard EN ISO 12996:2013 tentang dimensi diameter lubang, lebar, panjang, dan tebal pelat, jarak overlap, serta panjang area jepit. Gambar 1 dan 2 menunjukkan gambar mesin spesimen uji susunan rivet inline dan zig-zag. Jarak antar lubang rivet (pitch) serta jarak tepi pada spesimen uji dijaga agar tidak melebihi batas minimal yang dianjurkan standard API 541.17. Pada standard tersebut nominal jarak pitch serta jarak tepi diklasifikasi berdasarkan diameter lubang rivet. Jika diameter lubang rivet yang digunakan adalah 3,2 $\mathrm{mm}$, maka jarak pitch minimum adalah 11,2 mm. Jarak tepi minimal sebesar $7 \mathrm{~mm}$. Spesimen uji terdiri dari dua komponen, yakni pelat AL 2024-T3 serta rivet round NFL21217-T4. Berikut adalah sifat mekanik material pelat AL 2024-T3 (Tangahu et al., 2011).

Tabel 1

Sifat Mekanik AL 2024-T3

\begin{tabular}{ll}
\hline Sifat Mekanik & Nominal \\
\hline Yield Stress, $\sigma_{y}$ & $345 \mathrm{MPa}$ \\
Ultimate Tensile Strength $\sigma_{u}$ & $483 \mathrm{MPa}$ \\
Modulus Young, E & $73,1 \mathrm{GPa}$ \\
Modulus Shear, G & $28 \mathrm{GPa}$ \\
Poison's Ratio, v & 0,33 \\
\hline
\end{tabular}

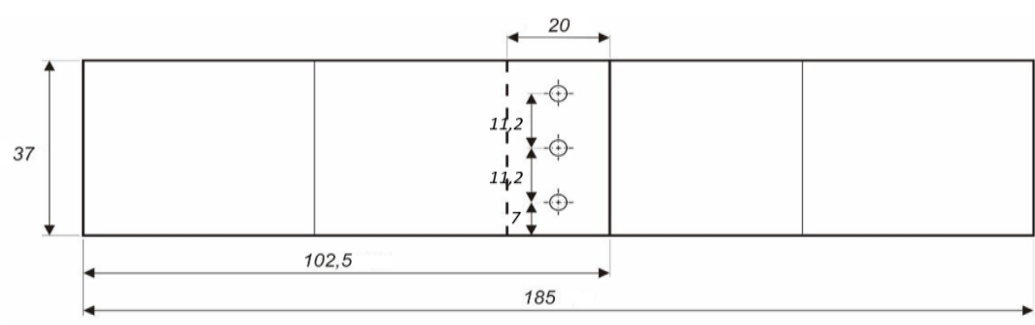

Gambar 1

Spesimen Uji Susunan Rivet In-line 


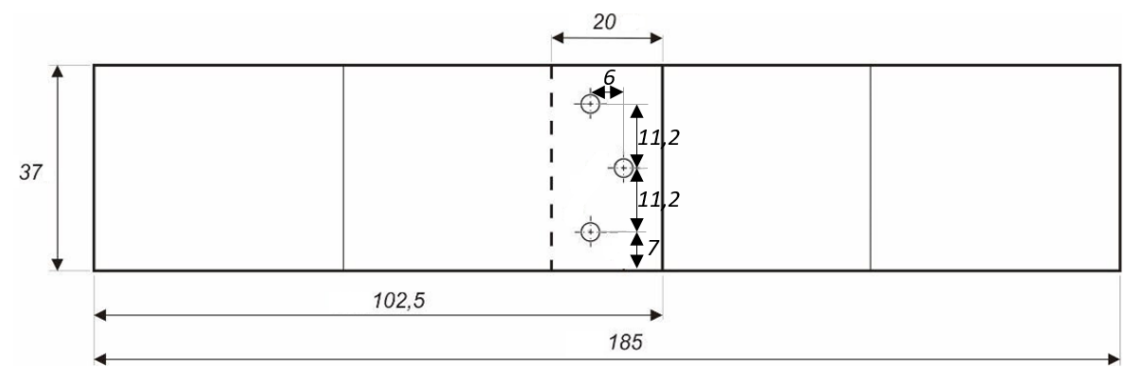

Gambar 2

Spesimen Uji Susunan Rivet Zig-zag

Proses manufaktur spesimen dilakukan dengan 4 urutan proses, yakni:

1. Pemotongan Pelat AL 2024-T3

Material sebagai sheet yang digunakan yaitu paduan aluminium 2024-T3 dengan tebal $0,8 \mathrm{~mm}$. Pemotongan material dilakukan sesuai dengan ukuran perancangan yaitu 102,5 x 37 mm (@4 buah) untuk dua buah spesimen. Setelah itu, tahap berikutnya dilakukan deburring untuk menghilangkan ketajaman pada sisi pelat. Hasil pemotongan dapat dilihat pada Gambar 3.

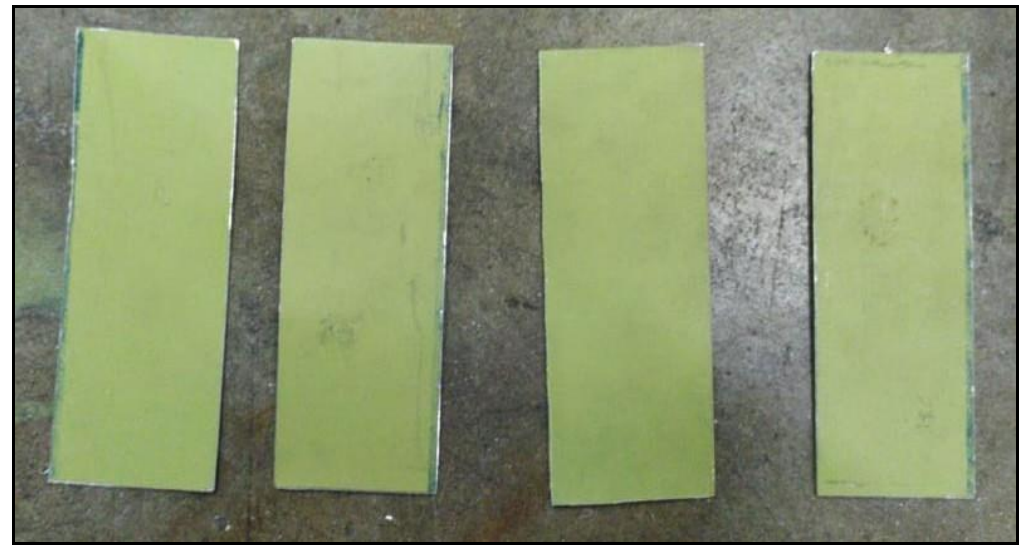

Gambar 3

Proses Pemotongan Spesimen Uji

2. Pencekaman Spesimen

Setelah dilakukan pemotongan, jepit pelat bagian atas dan bawah menggunakan pencekam. Jarak overlap antara pelat atas dan bawah sebesar $20 \mathrm{~mm}$ sesuai dengan nilai yang dianjurkan standard pengujian. Proses ini dilakukan dengan tujuan spesimen tidak bergerak ketika proses pengeboran dan riveting dapat dilihat pada Gambar 4. 


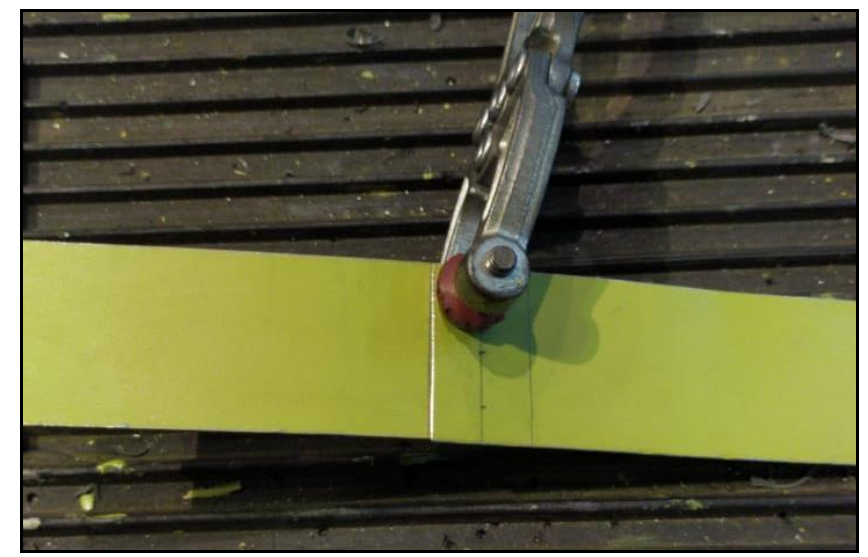

Gambar 4

Proses Pencekaman Spesimen Uji

3. Pengeboran Spesimen

Sebelum melakukan pengeboran, dilakukan penandaan lubang rivet yang akan dibor. Ukuran jarak sesuai dengan spesifikasi gambar mesin oada Gambar 1 dan 2. Setelah itu dilakukan pengeboran yang terdiri dua tahap untuk pengeboran lubang $\varnothing$ 3,2 mm seperti ditunjukan pada Gambar 5. Tahap pertama menggunakan mata bor $\varnothing$ 2,5 mm dan tahap kedua menggunakan mata bor $\varnothing 3,2 \mathrm{~mm}$ (Pambudi \& Ichsandi, 2017).

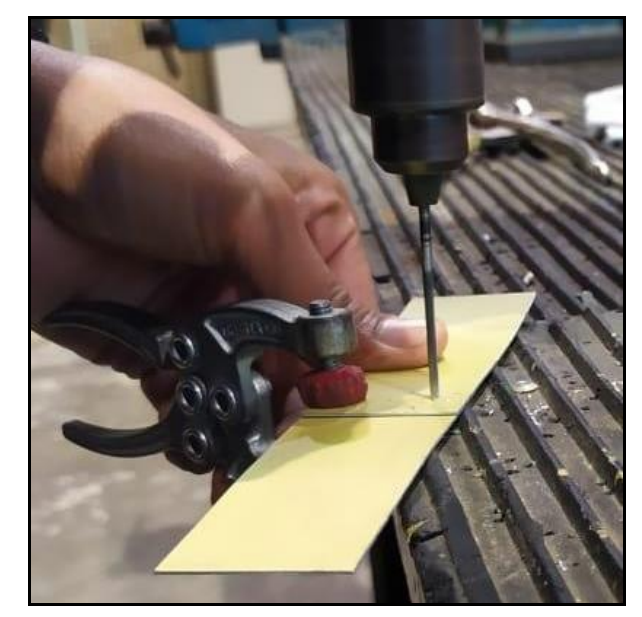

Gambar 5

Proses Pengeboran Spesimen Uji

4. Riveting Spesimen

Konfigurasi yang dipilih untuk penelitian ini menggunakan rivet round NFL21217-T4 paduan aluminium, diameter rivet 3,2 $\mathrm{mm}$ dan tebal sheet $0,8 \mathrm{~mm} 2024$ T3 paduan aluminium, proses riveting dapat dilihat pada Gambar 6. Proses ini diterapkan menggunakan spesifikasi dari Airbus Helicopters. 
Brilliant Dwinata, Adi Ganda Putra, Fauziyya Hafizha Riana

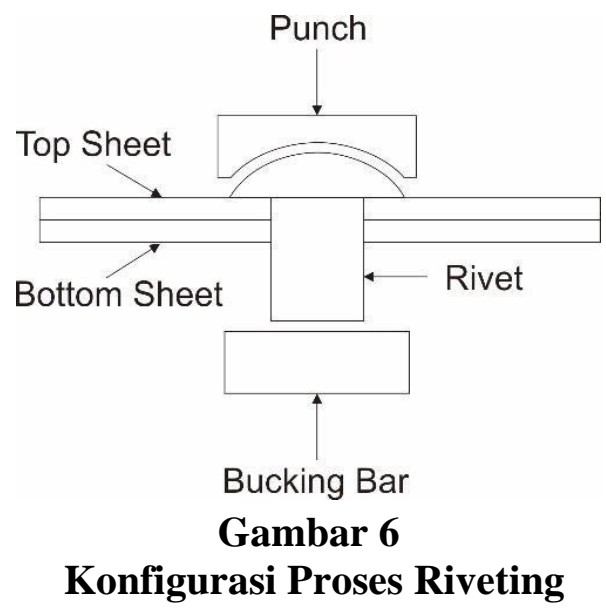

Proses riveting menggunakan squeezer jenis pneumatik. Parameter yang diterapkan selama membuat spesimen uji dalam tahap proses riveting dapat dilihat pada Tabel 2.

Tabel 2

Parameter Riveting

\begin{tabular}{cccc}
\hline Model & Diameter & Panjang & $\begin{array}{c}\text { Max Squeeze } \\
\text { Force }\end{array}$ \\
\hline Inline & $3,2 \mathrm{~mm}$ & $3,5 \mathrm{~mm}$ & $22.000 \mathrm{~N}$ \\
Zig-zag & $3,2 \mathrm{~mm}$ & $3,5 \mathrm{~mm}$ & $22.000 \mathrm{~N}$ \\
\hline
\end{tabular}

Proses ini merupakan kategori proses rivet secara semi otomatis seperti ditunjukan pada Gambar 7.

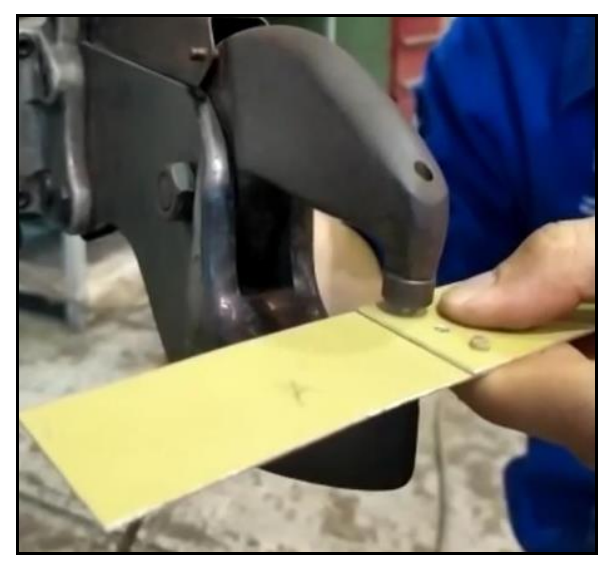

Gambar 7

Proses Riveting 
Hasil proses riveting untuk kedua model dapat dilihat pada Gambar 8.

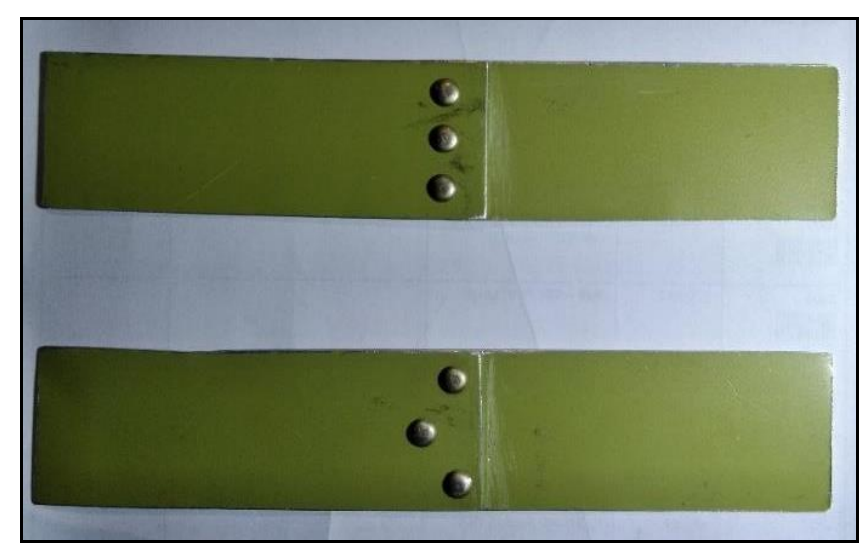

\section{Gambar 8}

Hasil Proses Riveting

\section{Pengujian Tarik Spesimen Secara Riil}

Pengujian spesimen dilakukan untuk mengetahui secara faktual nilai pembebanan yang diterima oleh sebuah sambungan rivet dengan konfigurasi yang sudah ditentukan. Untuk mendapatkan nilai tensile strength. Pengujian dilakukan dengan uji tarik dapat dilihat pada Gambar 9 sesuai dengan EN ISO 12996:2013. Pemodelan Pengujian Tarik Menggunakan Perangkat Lunak Ansys 2020 R2.

Diperlukan beberapa tahap melakukan pengujian menggunakan Ansys, diantaranya:

1. Pemodelan spesimen riveted lap joint.

2. Menentukan beban tarik maksimum (berdasarkan hasil pengujian riil) dan fixed support.

3. Melakukan proses Meshing dengan bentuk umum tetrahedral.

4. Menjalankan simulasi.

5. Mengetahui nilai dan melakukan analisis konsentrasi tegangan yang terjadi di tepi lubang rivet.

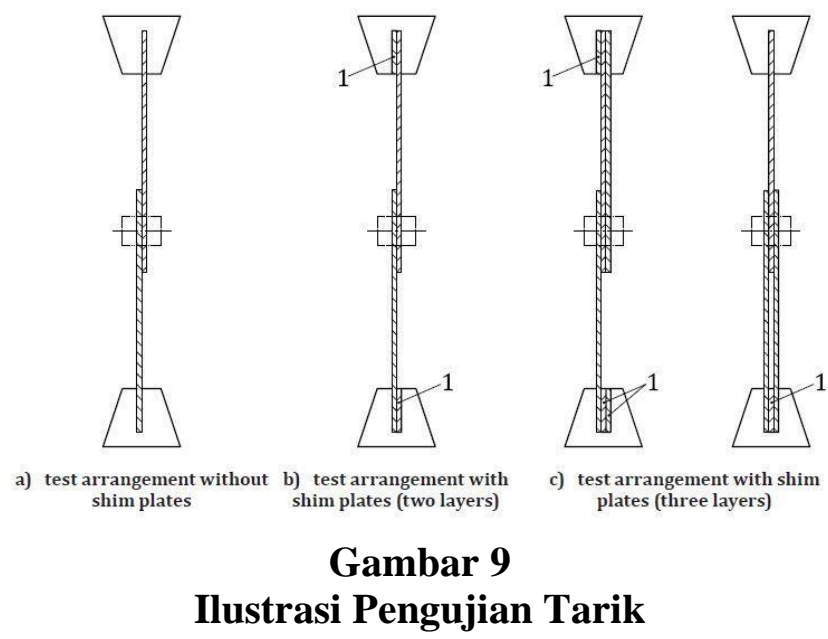




\section{Hasil dan Pembahasan}

\section{Pengujian Tarik Spesimen Secara Riil}

Pengujian tarik dilakukan untuk mencari nilai beban maksimum beserta tegangan tarik teoritis berdasarkan beban maksimum yang terukur. Hasil fisik pengujian tarik untuk spesimen dengan susunan Rivet inline dapat dilihat pada Gambar 10 dan spesimen dengan susunan Rivet zig-zag dapat dilihat pada Gambar 11 (Sari, Suteja, \& Syarif Hidayatullah, 2021). Jenis kegagalan pada spesimen dengan susunan rivet inline, terjadi sobekan pada pelat bagian bawah sepanjang lebar pelat dengan orientasi bidang tegangan tertentu.

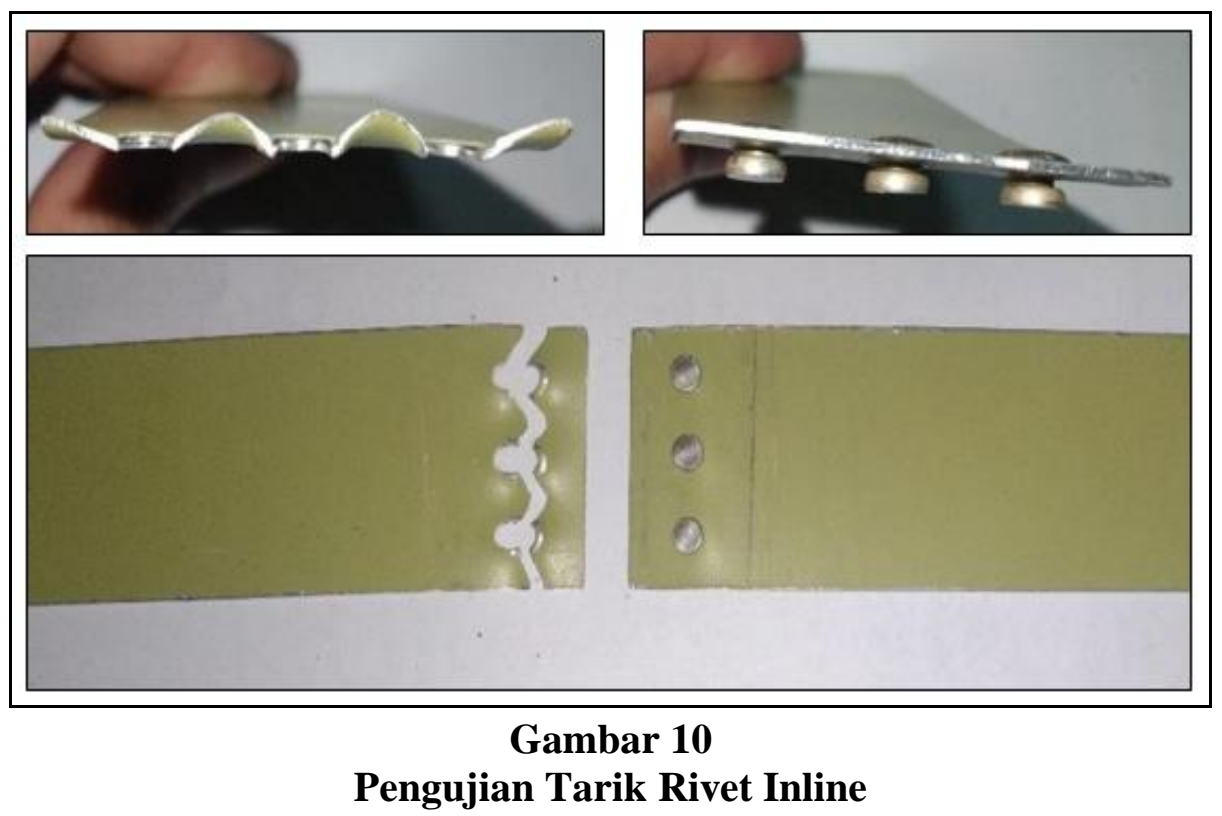

Jenis kegagalan pada spesimen dengan susunan rivet zigzag, terjadi sobekan pada pelat bagian atas maupun bawah di sekitar rivet dengan jarak tepi terdekat dengan ujung pelat.

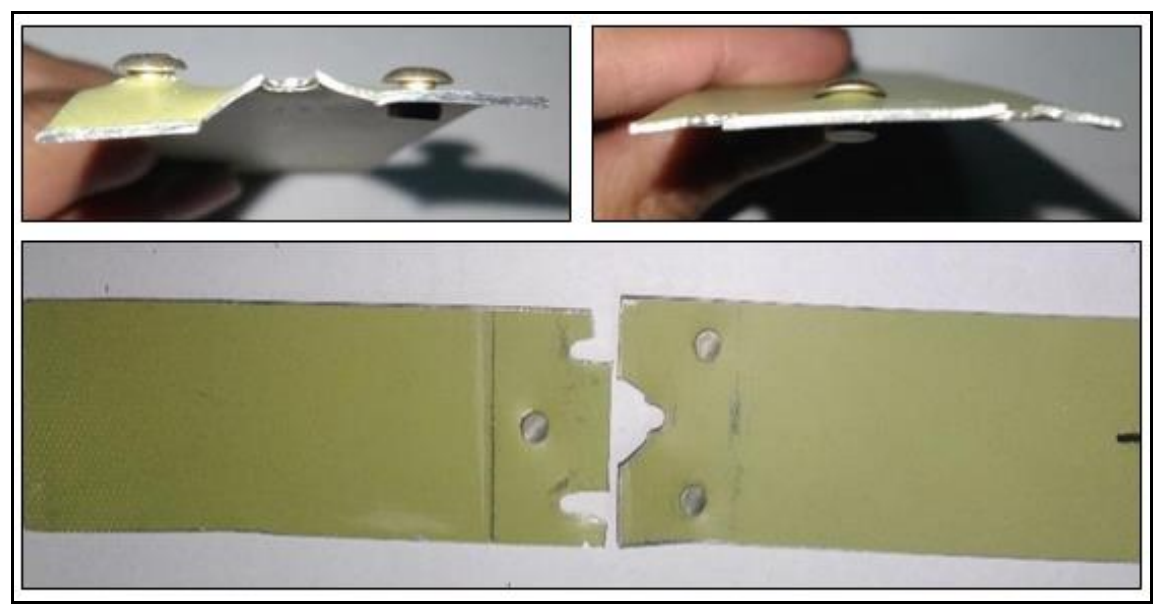

Gambar 11

Pengujian Tarik Susunan Rivet Zig-zag 
Nilai beban maksimum yang didapatkan dari pengujian tarik untuk kedua spesimen susunan rivet dapat dilihat pada Tabel 3. Spesimen dengan susunan rivet zigzag memiliki nilai beban maksimum yang lebih besar dibandingkan dengan susunan rivet inline (Kartawijaya, 2014).

Tabel 3

Parameter Riveting

\begin{tabular}{cc}
\hline Model & Beban Maksimum $(\mathbf{k N})$ \\
\hline Inline & 5,73 \\
Zig-zag & 6,01 \\
\hline
\end{tabular}

Setelah mengetahui nilai beban maksimum yang dapat ditahan oleh kedua spesimen, nilai tegangan normal dapat diprediksikan dengan formula dibawah ini:

$\sigma_{\max }=K_{t} \frac{F}{A}$

$\mathrm{K}_{\mathrm{t}}$ merupakan konstanta konsentrasi tegangan pada pelat yang terdapat lubang (Gambar 12), F merupakan beban maksimum, dan A adalah luas penampang yang efektif menahan beban (Budynas \& Nisbett, 2015).

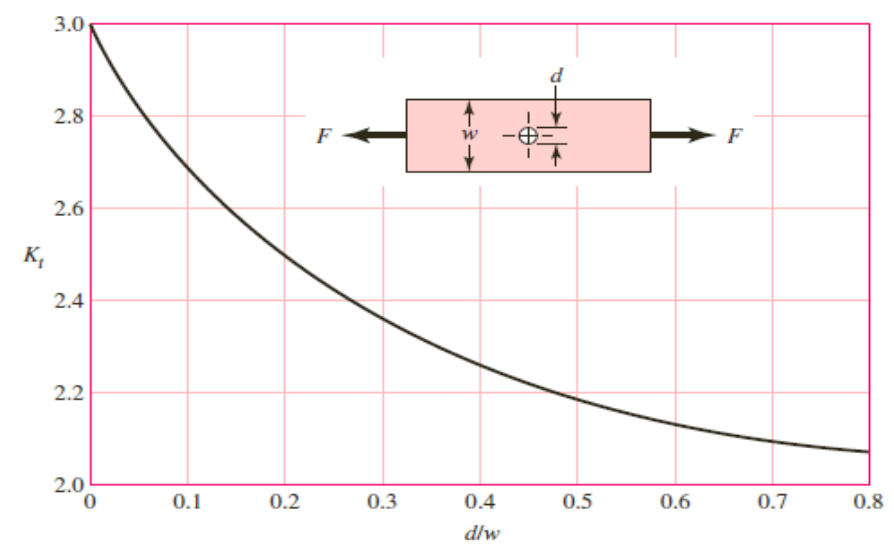

Gambar 12

Konstanta konsentrasi tegangan $K_{t}$

Dengan nilai lebar pelat sebesar $\mathrm{w}=37 \mathrm{~mm}$, dan nilai diameter lubang sebesar $\mathrm{d}=3,2 \mathrm{~mm}$, maka $\mathrm{d} / \mathrm{w}=0,086$. Nilai konstanta konsentrasi tegangan $\mathrm{Kt} \approx 2,7$.

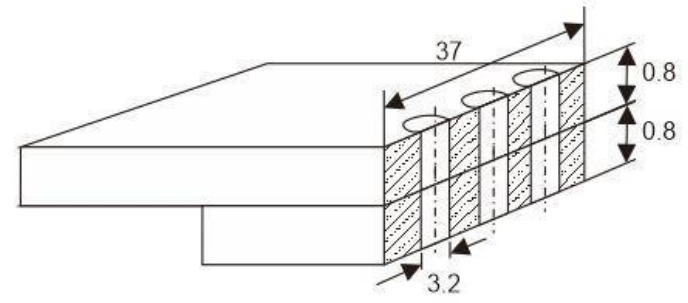

Gambar 13

Potongan spesimen dengan susunan rivet inline 
Besar tegangan normal maksimum yang terjadi pada spesimen dengan susunan rivet inline adalah:

$$
\begin{aligned}
\sigma_{\max } & =K_{t} \frac{F}{A}=2,7 \frac{5,73 \mathrm{kN}}{(37-(3 \times 3,2)) 0,8\left(\mathrm{~mm}^{2}\right)} \\
\sigma_{\max } & =705,78 \mathrm{MPa}
\end{aligned}
$$

Besar tegangan normal maksimum yang terjadi pada spesimen dengan susunan rivet zig-zag adalah:

$$
\begin{aligned}
\sigma_{\max } & =K_{t} \frac{F}{A}=2,7 \frac{6,01 \mathrm{kN}}{(37-(3 \times 3,2)) 0,8\left(\mathrm{~mm}^{2}\right)} \\
\sigma_{\max } & =740,28 \mathrm{MPa}
\end{aligned}
$$

Berdasarkan pendekatan teoritis nilai tegangan normal maksimal pada susunan rivet inline lebih kecil dibandingkan susunan rivet zig-zag. Dapat disimpulkan bahwa spesimen dengan susunan rivet zigzag dapat menahan beban lebih baik dibandingkan dengan spesimen dengan susunan rivet zig-zag.

\section{Simulasi Pengujian Tarik Spesimen Pada Perangkat Lunak Ansys 2020 R2}

Melalui perangkat lunak Ansys 2020 R2 ini dapat diketahui konsentrasi tegangan yang diterima oleh sambungan rivet untuk mempertegas hasil pengujian tarik secara riil. Analisis tersebut diperlukan beberapa parameter yang dibutuhkan oleh software dalam proses analisis, parameter-parameter tersebut tercantum dalam Tabel 1.

Setelah dilakukan pemasukan informasi parameter sifat mekanik pelat Al 2024-T3, langkah selanjutnya adalah memulai proses analisa pembebanan. Metoda perhitungan yang digunakan adalah metode tegangan ekuivalen Von Mises. metode tegangan ekuivalen Von Mises merupakan metoda analisa tegangan dengan beban statis untuk memprediksi tingkat keluluhan material terhadap kondisi pembebanan dari hasil pengujian tarik uniaksial. atau pada material ulet yang memiliki \% elongasi diatas 5\% (Budynas \& Nisbett, 2015). Al 2024-T3 memiliki nilai \% elongasi sebesar $23 \%$ sehingga dapat dikategorikan sebagai material ulet dan sesuai dengan kriteria penggunaan metoda tegangan ekuivalen von Mises.

Tegangan ekuivalen von Mises pada spesimen dengan susunan rivet inline terdapat pada pelat bagian bawah di sekitar lubang tengah rivet sebesar 865,1 MPa. Tegangan maksimum pada lubang sisi sebesar 826,7 MPa dan $819 \mathrm{MPa}$. Nilai tersebut sedikit lebih kecil dibandingkan nilai tegangan maksimum pada lubang tengah. Gradasi Tegangan Ekuivalen von Mises pada bagian pelat bawah Al 2024-T3 dapat dilihat pada Gambar 14. 


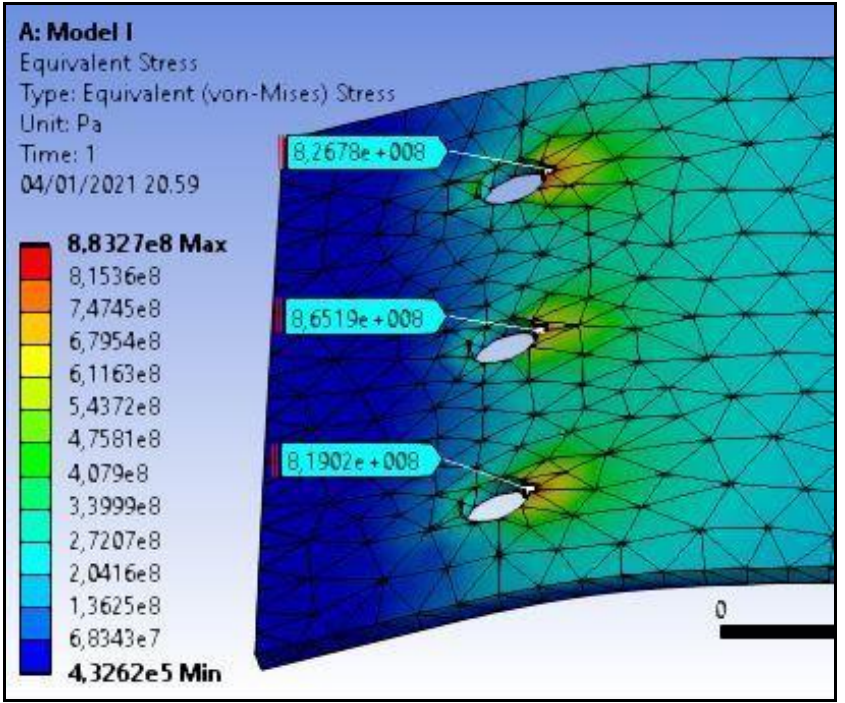

Gambar 14

Gradasi Tegangan Ekuivalen von Mises pada Bagian Pelat Bawah Al 2024-T3 Susunan Rivet Inline

Tegangan ekuivalen von Mises pada spesimen dengan susunan Rivet zig-zag terdapat pada pelat bagian bawah di sekitar lubang sisi sebelah kanan rivet sebesar 930,8 MPa. Tegangan maksimum pada lubang sisi sebelah kiri sebesar 906,6 MPa atau sedikit lebih kecil dibandingkan nilai tegangan sisi sebelah kanan. Sedangkan nilai tegangan ekuivalen von Mises pada lubang bagian tengah sebesar 626,6 MPa. Gradasi Tegangan Ekuivalen von Mises pada bagian pelat bawah Al 2024-T3 dapat dilihat pada Gambar 15.

Berdasarkan pendekatan numerik menggunakan perangkat lunak ANSYS 2020 R2, nilai tegangan normal maksimal pada susunan rivet inline lebih kecil dibandingkan susunan rivet zig-zag. Dapat disimpulkan bahwa spesimen dengan susunan rivet zigzag dapat menahan beban lebih baik dibandingkan dengan spesimen dengan susunan rivet zig-zag.

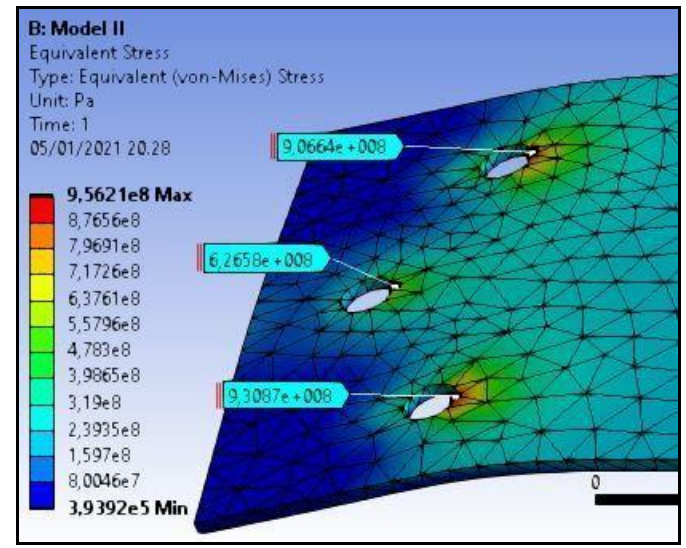

Gambar 15

Gradasi Tegangan Ekuivalen von Mises pada Bagian Pelat Bawah Al 2024-T3 Susunan Rivet Zig-zag 


\section{Analisa Hasil Pengujian}

Hasil pengujian tarik dari kedua spesimen dengan metoda pengujian secara riil dan metode pengujian numerik menggunakan perangkat lunak ANSYS 2020 R2 bertujuan untuk mengetahui tegangan normal maksimal yang diterima masingmasing spesimen. Tabel 4 mendeskripsikan rangkuman hasil pengujian dengan dua metoda yang berbeda:

\begin{tabular}{cccc}
\multicolumn{4}{c}{ Tabel 4 } \\
Parameter Riveting \\
\hline \multirow{2}{*}{ Model } & $\begin{array}{c}\boldsymbol{\sigma}_{\max } \\
\text { Beban }\end{array}$ & $\begin{array}{c}\boldsymbol{\sigma}_{\max } \\
\text { Maksimum }(\mathbf{k N})\end{array}$ & $\begin{array}{c}\text { Teoritik }(\mathbf{M P a}) \\
\text { Numerik }(\mathbf{M P a})\end{array}$ \\
\hline Inline & 5,73 & 705,78 & 865,1 \\
Zig-Zag & 6,01 & 740,28 & 930,8 \\
\hline
\end{tabular}

Berdasarkan indormasi diatas, spesimen dengan susunan rivet zigzag memiliki nilai beban maksimum yang lebih besar dibandingkan dengan susunan rivet inline. Hal ini disebabkan karena konfigurasi susunan rivet zig-zag memiliki jarak antar rivet yang lebih jauh dibandingkan dengan konfigurasi susunan rivet inline.

Hal ini dapat dipertegas mengunakan nilai tegangan normal maksimal teoritik yang dapat ditahan spesimen. Nilai tegangan normal maksimal pada susunan rivet zigzag lebih besar dibandingkan susunan rivet inline. Begitu pula nilai tegangan normal ekuivalen von Mises maksimal pada metoda pengujian numerik menunjukan bahwa susunan rivet zigzag lebih besar dibandingkan susunan rivet inline.

\section{Kesimpulan}

Hasil pengujian Tarik secara rill menunjukkan bahwa susunan rivet zig-zag dapat menerima beban maksimum sebesar $6,01 \mathrm{kN}$ sedangkan susunan rivet inline $5,73 \mathrm{kN}$. Sedangkan pengujian numerik menunjukkan bahwa tegangan maksimum ekuivalen von-Mises pada susunan rivet zig-zag sebesar 930,8 MPa sedangkan susunan rivet inline sebesar 865,1 MPa. Dapat disimpulkan bahwa spesimen dengan susunan rivet zigzag dapat menahan beban lebih baik dibandingkan dengan spesimen dengan susunan rivet zig-zag. 


\section{BIBLIOGRAFI}

Abdullah, S., Beden, S. M., \& Ariffin, A. K. (2011). Fatigue crack growth simulation of aluminium alloy under cyclic sequence effects. Aluminium Alloys, Theory and Applications, 237-258.Google Scholar

Agustin, Ami Hilda, Gandhiadi, G. K., \& Oka, Tjokorda Bagus. (2016). Penerapan Metode Fuzzy Sugeno Untuk Menentukan Harga Jual Sepeda Motor Bekas. EJurnal Matematika, 5(4), 1751-2303. Google Scholar

Budynas, Richard, \& Nisbett, J. Keith. (2015). Shigley's Mechanical Engineering Design. In Mechanical Engineering. Google Scholar

Cheraghi, S. Hossein. (2008). Effect of variations in the riveting process on the quality of riveted joints. The International Journal of Advanced Manufacturing Technology, 39(11-12), 1144-1155. Google Scholar

Cholik, Cecep Abdul. (2017). Pemanfaatan Teknologi Informasi Dan Komunikasi Untuk Meningkatkan Pendidikan Di Indonesia. Syntax Literate; Jurnal Ilmiah Indonesia, 2(6), 21-30. Google Scholar

Hondro, Rivalri Kristianto. (2018). Aplikasi Enkripsi Dan Dekripsi Sms Dengan Algoritma Zig Zag Cipher Pada Mobile Phone Berbasis Android. Google Scholar

Kartawijaya, Irwan. (2014). Prosiding Seminar Nasional. Prosiding Seminar Nasional Biodiversitas Dan Ekologi Tropika Indonesia (BioETI) Universitas Andalas, 1. Google Scholar

Lei, Changyi, Bi, Yunbo, Li, Jiangxiong, \& Ke, Yinglin. (2017). Effect of riveting parameters on the quality of riveted aircraft structures with slug rivet. Advances in Mechanical Engineering, 9(11), 1687814017734710. Google Scholar

Mucha, Jacek. (2017). Blind Rivet and Plastically Formed Joints Strength Analysis. Acta Mechanica Slovaca, 21(1), 62-69. Google Scholar

Pambudi, Lilianto Rio, \& Ichsandi, Mustar. (2017). Metode Pelaksanaan Pembangunan Terowongan Pengelak (Tunnel) Pada Proyek Waduk Bendung Ponorogo. Institut Teknologi Sepuluh Nopember. Google Scholar

Sari, Nasmi Herlina, Suteja, S. T., \& Syarif Hidayatullah, S. T. (2021). Pengantar Inhibitor Korosi Alami. Deepublish. Google Scholar

Tangahu, Bieby Voijant, Sheikh Abdullah, Siti Rozaimah, Basri, Hassan, Idris, Mushrifah, Anuar, Nurina, \& Mukhlisin, Muhammad. (2011). A review on heavy metals $(\mathrm{As}, \mathrm{Pb}$, and $\mathrm{Hg}$ ) uptake by plants through phytoremediation. International Journal of Chemical Engineering, 2011. Google Scholar

Zamzamy, Achmad Siddiq. (2018). Desain Dan Pembuatan Model Kafo (Knee Ankle 
Brilliant Dwinata, Adi Ganda Putra, Fauziyya Hafizha Riana

Foot Orthosis) Berdasarkan Antropometri Tubuh Orang Indonesia.

\section{Copyright holder:}

Brilliant Dwinata, Adi Ganda Putra, Fauziyya H.R. (2021)

\section{First publication right:}

Syntax Idea

This article is licensed under:

(c) (i) (?) 